Arab World English Journal (AWEJ) Special Issue on Covid 19 Challenges April 2021

DOI: https://dx.doi.org/10.24093/awej/covid.25

\title{
Technology, Pedagogy \& Assessment: \\ Challenges of COVID19-Imposed E-Teaching of ESP to Saudi Female PY Students
}

\author{
Amatul Hafeez Alvi \\ Faculty of Languages \& Translation \\ King Khalid University, Saudi Arabia \\ Corresponding Author: aalhfed@kku.edu.sa \\ Syed Muhammad Bilal \\ Razak Faculty of Technology \& Informatics \\ Universiti Teknologi Malaysia, Malaysia
}

\author{
Aisha Abdul Rahim Alvi \\ Razak Faculty of Technology \& Informatics \\ Universiti Teknologi Malaysia, Malaysia
}

Received: 2/13/2021

Accepted: $3 / 14 / 2021$

Published: 4/26/2021

\begin{abstract}
The Coronavirus Disease (Covid-19) triggered substantial shifts in the education systems worldwide as teaching and learning have had to shift from face-to-face to an entirely virtual model due to the closure of educational institutes. The present paper is a descriptive-analytical investigation of the challenges of the current pandemic-imposed E-teaching of English for Specific Purposes (ESP) courses to female preparatory (PY) year students at King Khalid University (KKU). It identifies teachers' and students' responses about the ongoing issues with E-teaching of ESP with to put practical solutions to them. The study is conducted at The University Center for Girls' Studies- Al-Samir Campus-Abha during the academic year 2020-2021. Twenty English Language instructors at the English Language Center (ELC) and eighty students of the preparatory year at the College of Medicine enrolled in Intensive English Course (Njl-019) participated in the study. It adopts mixed qualitative methodology with the teachers' semi-structured interview and students' questionnaire as tools to collect data, and descriptive analysis as a method to interpret data. The study finds out reciprocity of teachers' and students' responses in pinpointing the factors posing serious challenges in teaching and learning ESP courses as majorly related to technology, pedagogy, and Assessment. Considering these challenges, the study puts forth practical suggestions to promote virtual teaching and learning of ESP courses. The suggested solutions are hoped to help providing successful standards for virtual ESP teaching and learning as per the constraints of quality modern education.

Keywords: Assessment, Covid-19, ESP, E-teaching, King Khalid University, pedagogy, Saudi Arabia, technology

Cite as: Alvi, A. H., Bilal, S.M., \& Alvi, A.A. (2021). Technology, Pedagogy \& Assessment: Challenges of COVID19-Imposed E-Teaching of ESP to Saudi Female PY Students. Arab World English Journal (AWEJ) Special Issue on Covid 19 Challenges (1) 334- 353.

DOI: https://dx.doi.org/10.24093/awej/covid.25
\end{abstract}




\section{Introduction}

Epidemics are one of the inescapable aspects of life and the most challenging and threatening calamities that strike the planet and put man in front of the challenge of survival. Beside the dramatic loss of human lives and the unprecedented challenge to human public health, social, cultural, political, economic, and psychological aspects, the disruption of education systems around the globe caused by pandemics is formidably challenging.

Coronavirus Disease is the recent yet most hazardous and contagious disease that first arose in Wuhan, China in 2019. It was later coded "COVID-19" abbreviating "Coronavirus Disease 2019" and was declared as a global pandemic by the World Health Organization (WHO). The mortality rate and the uncontrollable spread were gravely distressing. The major symptoms of Coronavirus include sore throat, runny nose, relentless coughing, or sneezing, breathing difficulty and lethargy. Research shows that older people and those with underlying medical problems like cardiovascular diseases, diabetes, chronic respiratory disease, and cancer were more likely to develop serious illnesses from coronavirus (W.H.O, 2020).

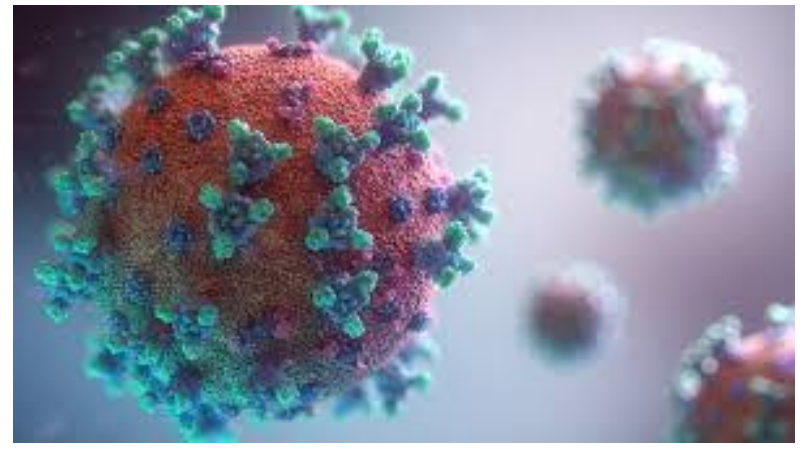

Figure 1. The Morphology of Coronavirus: the blue-colored club-shaped viral spike polymers create the look of a corona surrounding the virion when observed with an electron.

To contain the spread of the virus, all world countries started adopting different safety measures in line with WHO (2020). Emergency was declared in all security and health institutes and complete lockdowns, social distancing and quarantines were imposed all citizens were asked to continue from homes to curtail the spread of the virus.

This pandemic has caused huge universal disruption of education impacting learners and teachers worldwide in kindergarten, primary to secondary schools, Technical and Vocational Education and Training (TVET) institutions and universities, all countries across the world closed down educational institutes in an effort to mitigate the pandemic. According to the United Nations Educational, Scientific and Cultural Organization (UNESCO, 2020), monitoring, over 100 countries implemented nationwide closures, impacting over half of the world's student population. Moreover, 94 percent of learners internationally were affected by the pandemic by mid-April 2020, representing 1.58 billion children and youth, from pre-primary to higher education, in 200 countries. 


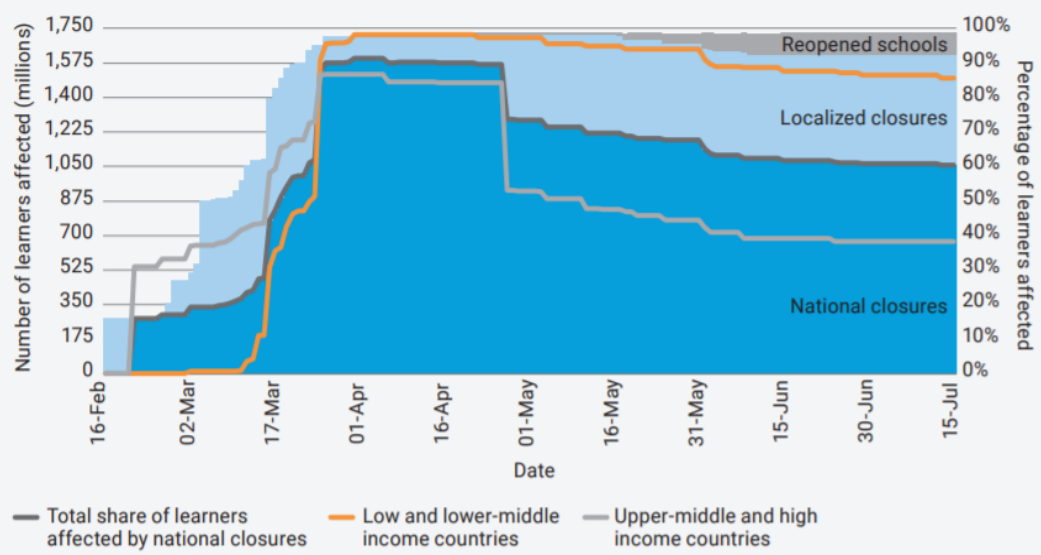

Figure 2. Number of students affected by school closures globally (Adapted from UNESCO, 2020)

With a population of more than 34 million, Saudi Arabia is the second-largest country in the Arab world. Saudi Arabia is among the leading countries that hastened to contain the crisis of Covid-19 outbreak by implementing initiative and unprecedented precautionary measures beside substantial support packages to prevent the spread of the virus. A national committee consisting of the government ministers for Health, Education, FDA, Interior and many others was established to follow global updates and to prepare for the possible introduction and spread of the virus from early January 2020. Travel ban was implemented, and all international flights were stopped from and to the Kingdom. Umrah was entirely suspended by March 4th and the two holy mosques in Makkah and Madinah were put to daily closure for cleaning and disinfection. In March 2020, the Saudi government shifted schools and universities to remote learning and virtual classrooms. Furthermore, the five daily prayers in all hundreds of thousands of mosques across the country were banned and all Muslims in Saudi Arabia were requested by religious authorities to pray at homes for the very first time in the history of the Kingdom. Digital health was quickly activated and utilized for several services that allow people to seek medical help and receive medical prescriptions without the need to visit the medical centers. (Algaissi, Alharbi, Hassanain, \& Hashem, 2020)

The Saudi Center for Disease Prevention and Control (SCDPC) abruptly issued health protocols and guidelines and public health considerations. Awareness campaigns were initiated, and governmental local awareness messages were also daily via text messages and media outlets. By the end of March 2020, Saudi Arabia issued a curfew and imposed a strong financial penalty on lawbreakers. Eventually, the Saudi government enforced lockdown and isolation of several suburbs and districts in major cities and started extensive mass testing in communities.

As with countries around the world, Saudi Arabia suspended attendance at all educational institutes and continued the teaching and learning process through alternative means using television, online provision, and instructional packages. It had ensured the continuation of the remote educational process and maintained the safety for more than six million students in public schools and universities according to the UNESCO reports. The Saudi ministry of education established a specialized committees and work teams to ensure the readiness of the education and 


\section{Arab World English Journal (AWEJ) Special Issue on Covid 19 Challenges April 2021}

Technology, Pedagogy \& Assessment: Challenges of COVID19

Alvi, Bilal, \& Alvi

training system to produce results that guarantee the safety of education personnel while the UNESCO admitted that Saudi Arabia's transition to distance learning had been a "success story" as online classes were set up within ten hours of the decision to close schools in late March and lessons were broadcast via satellite on $20 \mathrm{TV}$ channels. Additionally, lessons were also available on YouTube where views reached more than 61 million. Nevertheless, in higher education, 27 public universities hosted two million virtual classes and more than six million panel discussions in the second semester of the academic year 2019-2020.

Located in the Southern region of Saudi Arabia, King Khalid University (KKU) is one of the leading universities in the kingdom with more than seventy thousand students and over twenty sites. The university offers Bachelors, Masters, Ph.D. degrees in various Arts and Sciences subjects beside many other short courses, diplomas, and training. The E-Learning Management System (LMS) and Distance Learning Education of King Khalid University is among the top available commercially in KSA believing in E-Learning as "the means of making education better, cheaper, more available or more responsive" (Mason \& Rennie, 2008, p. 2). The LMS is supported by the Classroom Capture Application, Authoring Tools, e-Assessments, Virtual Classroom Tools, and a highly capable Learning Object Repository (LOR) that can share learning objects drawn from a variety of international open learning resources and content providers (Alwalidi \& Lefrere 2010). The system is overall fully supported and easily accessible. The courses can be taught as fully online mood or blended mood. When the ministry of education announced the switch to E-learning as an essential measurement to cope up with Covid-19 spread in the country, the sudden and inadvertent decision has undoubtedly caused severe challenges for students, educators, parents, and the society as a whole. KKU, however, did not face big problems as E-Learning was already introduced and practiced as an optional teaching and learning style. Nonetheless, the unanticipated and swift mandatory implementation of virtual teaching for all brought forth a couple of challenges that handicapped quality Eteaching and Learning, especially in the first preparatory year at the university where students are just transferred from school to university with the undeniable existence of the psychological and academic gap between both education levels. The preparatory year aims to fill this gap between high school and university and makes the transition easier, empowering students to succeed in this new environment, and giving them the skills to adjust and flourish in the new challenging university educational system with its unique atmosphere and methods of evaluation, quality teaching and learning at this level is highly necessitated.

English for Specific Purposes (ESP) is an oriented form of language teaching that addresses the demands of certain communities of learners interested in obtaining some professional skills and practicing job-related performances. ESP displays some differences from ESL (English as a Second Language), EFL (English as a Foreign Language) and EGP (English for General Purposes) due to its oriented focus. Hutchinson and Waters give a short but detailed account of it, underlining the fact that it has to be perceived as an approach, and not as a product. "ESP is not a particular kind of language or methodology, nor does it consist of a particular type of teaching material. Understood properly, it is an approach to language learning, which is based on learner need" (Hutchinson \& Waters, 1987, p. 19).

Teaching ESP courses is to some extent a challenging task for teachers and learners as it is it is "language in context" that entails real life learning situations and scenarios that tend to 
imitate specific working or professional settings the ESP students are interested in. ESP course emphasizes on the value of exercising the necessary English language skills students would primarily utilize in their future fields of activity, rather than concentrating on grammar, vocabulary, and language structures. Therefore, Lorenzo Fiorito stresses that ESP "assesses needs and integrates motivation, subject matter and content for the teaching of relevant skills" (Lorenzo, 2005, p. 2).

Teaching ESP courses has always been a daunting task and a major experiment test for every teacher in charge of it as it focuses on the specific needs of the learners and concentrates more on language in context and the students' prerequisite of acquiring a particular set of professional skills and job-related functions. These challenges are intensified in virtual learning which is vastly different from the traditional face-to-face learning system. The paper discusses the ongoing issues with teaching ESP online with the aim of putting practical solutions to ensure successful ESP E-learning and teaching.

\section{Research Questions:}

The study aims at answering the following research questions:

1) What are the current challenges confronting English Language instructors in the E-teaching of ESP courses to preparatory year female students at King Khalid University?

(2) What are the current challenges facing preparatory year female students in the E-learning ESP courses at King Khalid University?

(3) What effective solutions can be suggested to overcome the challenges of E-teaching and Elearning on ESP courses at King Khalid University?

\section{Research Objectives:}

The objectives that are expected to be achieved by this study are:

1) To identify the current challenges confronting English Language instructors in the E-teaching of ESP courses to preparatory year female students at King Khalid University?

( 2 To identify the current the current challenges facing preparatory year female students in the Elearning ESP courses at King Khalid University?

(3) To propose effective solutions to overcome the challenges of E-teaching and E-learning on ESP courses at King Khalid University?

\section{Literature Review}

Covid-19's challenges in teaching English Language courses have inspired many educators and researchers globally to address these continuous challenges. In Saudi Arabia, the year 2020 witnessed a colossal momentum in the research body related to the impact of Covid19 on Education starting from the very early childhood education to higher education and concentrating on variety of scientific, social, financial, health and language fields. 


\section{Arab World English Journal (AWEJ) Special Issue on Covid 19 Challenges April 2021}

Instantaneously, studies related to Teaching and learning English language flourished with educators and researchers delving into the epidemic-driven issues hampering the successful online delivery of English language subjects. Many studies related to English language teaching in Higher Education appeared where different perspectives of the concurrent situation are discussed.

Akhter (2020) conducted a study on the hundred EFL Saudi students from different colleges to explore the problems caused by the pandemic imposed virtual teaching of English Listening course. Highlighting the major problems hampering learning Listening skills effectively, Akhter finds out that online learning is dissatisfactory due to the lack of planning and preparation. The technical and methodological drawbacks of teachers hinder successful learning and cause low achievement levels of students. According to Akhter, online teaching amidst covid-19 crisis has been effective, yet "Change in attitudes and technological literacy would help students gain confidence to be successful with a positive vibe in their courses" (Akhter, 2020, p. 7). She suggests comprehensible training for teachers to optimize their online learning activities, develop their information literacy and correct their misperceptions about online learning which will consequently make the students comfortable with online learning.

Hakim (2020) investigated technology-integrated classrooms and the challenges facing EFL teachers in Saudi Arabia during the COVID-19 pandemic. Hakim's study sample included fifty English Language instructors from King Abdul Aziz University, Jeddah, Saudi Arabia. The most common challenges she highlighted were the inability to access the modern equipment, interrupted or weak internet connection, learners' low motivation level and attention deficit. However, the study reported a positive inclination of many language instructors towards technology in EFL online classes. The study's findings assert that "online techno-led EFL classes, though effective, still have issues that should be addressed by the teachers, learners and, mainly, by the institutional management" (Hakim,2020, p. 6). He recommended the productive use of techno-led online EFL classrooms, focusing on strategic skill-based learning taking place and establishing a strong virtual link between the instructors and learners.

Rahman (2020) explores the challenges of teaching English as a foreign language online during the COVID-19 pandemic in Saudi Arabia and teachers' satisfaction with online English language learning classes. The study is conducted designing a questionnaire for fifty EFL faculty members of various Saudi Arabian universities. The study reveals promising results reflecting the usefulness and efficacy of teaching English as a foreign language online if proper training and orientation programs for teachers and students are implemented, and online language learning platforms and tools are up to date.

Almekhlafy (2020) highlights the perceptions of Saudi students toward the Blackboard application in the process of learning Preparatory Year (PY) English courses as the mere tool of learning and the impact of the students' perceptions on their use of Blackboard. Surveying one hundred and twenty-six students of level one and one hundred and two students from level two at the preparatory year program at Najran University, the researcher compares the perceptions of both groups and finds that level one students have higher impression with BB than level two students. The findings suggest that the students' prior experience of e-learning via Blackboard impacts the students' perceptions. 


\section{Arab World English Journal (AWEJ) Special Issue on Covid 19 Challenges April 2021}

Mahyoob (2020) examined the difficulties and hurdles encountered by English language learners (EFL) in Science and Arts College, Alula, Taibah University, Saudi Arabia, during shifting to virtual learning in the second semester of 2020. According to the study, COVID-19 pandemic has "negatively influenced the learners' performance and learning outcomes" (Mahyoob, 2020, p. 10). The study evaluated the learners' new experiences in online education and evaluate the practicability of the virtual approaches of learning. Analyzing one hundred and eighty-four learners' responses to a based questionnaire, the study found that the major problems that impact online EFL learning during COVID-19 are due to technical, academic, and communication challenges. The study results revealed that most EFL learners are not satisfied with continuing online learning, because they are not achieving the anticipated improvement in language learning performance.

Dahmash (2020) explored the benefits and challenges of blended learning during the spread of COVID-19 from the perspective of English as a foreign language (EFL) student at King Saud University. The results show that blended learning profited the EFL students by endorsing their writing skills and persuading them to search online, alongside fitting their circumstances and being economical. On the other hand, the study also identifies that the challenges EFL students faced included technological troubles, weaknesses of the instructor's performance, problems with online tests, attitudes to online learning and limited resources, and the university council's decisions. The paper recommends utilizing the benefits and overcoming the challenges of blended learning while teaching English in an EFL context.

Karim and Hasan (2020) conducted a study at of Prince Sattam bin Abdulaziz University at Al Kharj, Saudi Arabia to observe the challenges and prospects of a virtual system of learning from the undergraduate EFL students' viewpoint. A structured questionnaire was created and employed as the research instruments for collecting the data and it was carried out among 221 students The study finds that about $80 \%$ of students agreed that virtual classes are more convenient than regular classes and $66 \%$ of the students are satisfied with the new virtual system of learning, $60 \%$ of students feel more confident during online classes than face-to-face classes, and 59\% students feel that remote learning could replace the face-to-face mode of learning. On the other hand, only $23 \%$ of students faced internet issues. The findings show that most of the learners are prefer the virtual method of learning which is "a huge achievement that such an overwhelming number of students are feeling satisfied with the online mode of learning" (Karim \& Hasan, 2020, p. 213). Hence the curriculum designers should consider the pedagogical practices and students' preferences while designing the syllabus.

Al-Ahdal and Al-Qasham (2020) scrutinize the situation of online learning and assessment surveying professors at Saudi Electronic University and Qassim University. The study results show that majority of the faculty members admitted having an intermediate computer proficiency level on online learning assessment. They often use online quizzes, forum posts, evaluations, and reviews; and they always use easy tasks as online assessments. Resultantly, cheating is easy to do and difficult to detect; and the output and performance are more difficult to perform electronically. The study stresses that online students require a more organized framework and more support to keep on schedule and present. 
Al-Nofaie (2020) identifies the advantages and challenges of online learning to understand the perception of EFL students at Taif University, Saudi Arabia, and their learning experiences during the pandemic period. The study compares the synchronous and asynchronous aspects of BB in teaching Morphology subject. It shows that students preferred the asynchronous environment to the synchronous one due to its flexibility. Nevertheless, the study reveals that virtual education is not always appealing to students. The study recommends university authorities to set out more practical educational plans in the case of emergencies to enlighten the practices of university instructors and designers of professional development courses in the near future.

Al-Ghammas (2020) examined the perceptions of university faculty members towards the application of online assessment using the 'Blackboard' platform during Covid-19. One hundred and seventy-one faculty members of English departments at universities throughout Saudi Arabia participated in his study. Although participants of both genders positively remarked on the use of online assessments, they had concerns about the online assessment-related dimensions, i.e., validity, practicality, reliability. and security. "The biggest concern for language instructors using online assessment is cheating, which is difficult to avoid" (Al-Ghammas, 2020, p. 170). The study asserts that COVID-19 could be the turning point in dealing with evaluation issues as large classes, lack of government resources, and the need to make teaching and assessment appropriate for the young generation known as digital natives. Full online assessment practices in Saudi Arabia in which faculty can be implemented all times.

Generally, all the above-mentioned studies conclude some sort of common dissatisfaction and concern with the issues related to teaching EFL courses online that need to be addressed. However, they have tackled EFL and GE skills generally. No study to date has tackled ESP courses that differ in their focus, nature, constraints, and importance from EFL and GE. The present study aims at filling this vital gap and adding to the body of literature related to the effects of covid-19 on teaching and learning ESP courses within the Saudi higher education context. It targets teaching ESP courses as the most challenging language subject and emphasizes the role of proper online teaching practice in achieving the learning outcomes of the course. The study suggests significant required improvements in online teaching practices that help the effective delivery of the ESP lessons and better engage the students boosting their linguistic competencies in their professional fields.

\section{Methodology}

\section{Instruments:}

The study aims at examining the challenges of teaching English in Medicine course to Preparatory Year students from teacher's and students' perspective. For this purpose, mixedmethod was adapted. The data collection instruments are semi-structured interviews and questionnaires. The chosen methods are particularly apt for acquiring a specific data type (Lawthom \& Tindall, 1994). Semi-structured interviews are those in-depth interviews where the respondents must answer preset open-ended questions and thus are widely employed by different healthcare professionals in their research. Semi-structured, in-depth interviews are utilized extensively as interviewing format possibly with an individual or sometimes even with a group (Corbin \& Strauss, 2008). These interviews are based on semi-structured interview guide, which is a schematic presentation of questions or topics that needs to be explored by the interviewer. 
On the other hand, Questionnaire is an effective research instrument that consists of a series of questions to gather information from respondents (Kabir, 2016). A questionnaire was designed to consist of sixty questions divided into three parts: the first part is associated with the participants' responses to challenges related to technology, the second part asks questions pertaining to the challenges pertaining to pedagogy, the third part focuses on the challenges related to evaluation.

\section{Participants:}

The interviewees are twenty English Language Instructors at ELC, KKU, while the questionnaire was sent to for eighty students of the preparatory year at the College of Medicine enrolled in the Intensive English Course (Nj1-019).

\section{Study Context:}

The study took place at King Khalid University, the Joint Programs, English Language Center, Al-Samir Female Campus, Abha, during the academic year 2020-2021 (1441-1442 H). King Khalid University is one of the Saudi government universities, located in the southern regain in Abha city. KKU hosts more than 73000 students in more than 47 colleges and departments spread in the south region of Aseer.

The Joint Programs at KKU is a program that lays the educational foundation and sets up the principles for affiliating and nurturing all subsequent education for candidates to the Bachelors degree in different fields. It prepares students to join various academic pathways and ensures high rates of success. It acquaints the students with the various academic disciplines at the university and integrates them into the university environment before deciding on their future fields of study at the different disciplines offering basic skills courses in English, computer, engineering, and medical language to accustom students to the knowledge and learning environment of the university. The program at KKU continues for one year including two semesters as well as an optional summer extension to give students the chance to re-study the failed subjects and enable them to pass the program and proceed to their specialty colleges complying with the criteria of each college. Passing the PY courses successfully is a requisite for proceeding to the first college year and continuing studies at any discipline.

English Language Center (ELC) at King Khalid University (KKU) offers intensive and non-intensive courses to set students on the right track towards their professional careers and enrich their cultural backgrounds. ELC aims at preparing students to study their academic majors in English by establishing English language courses for academic and special purposes for all students in all colleges and assisting them in using the English language for their own communicative purposes. The center focuses on enhancing and upgrading the level of students' language skills and keeping students abreast of the global developments in their specialties by familiarizing them with the digital resources and raising the level of educational attainment in the various colleges of the university.

At KKU, ESP courses are designed and taught at the ELC during the preparatory year to prepare first-year students of Medical \& Health Sciences, Engineering, Computer Science, Law and Business departments in their respective fields of specializations, enhancing their employeelevel of English and competence in various professional areas. For Health Sciences students, 
ELC offers Intensive English Course (019-Njl) with six credit hours and twenty contact hours, teaching three main subjects: Reading and Writing, Listening and Speaking and English in Medicine. While Reading and Writing and Listening and Speaking focus on general language skills, English in medicine concentrates on Professional English for Medical purposes.

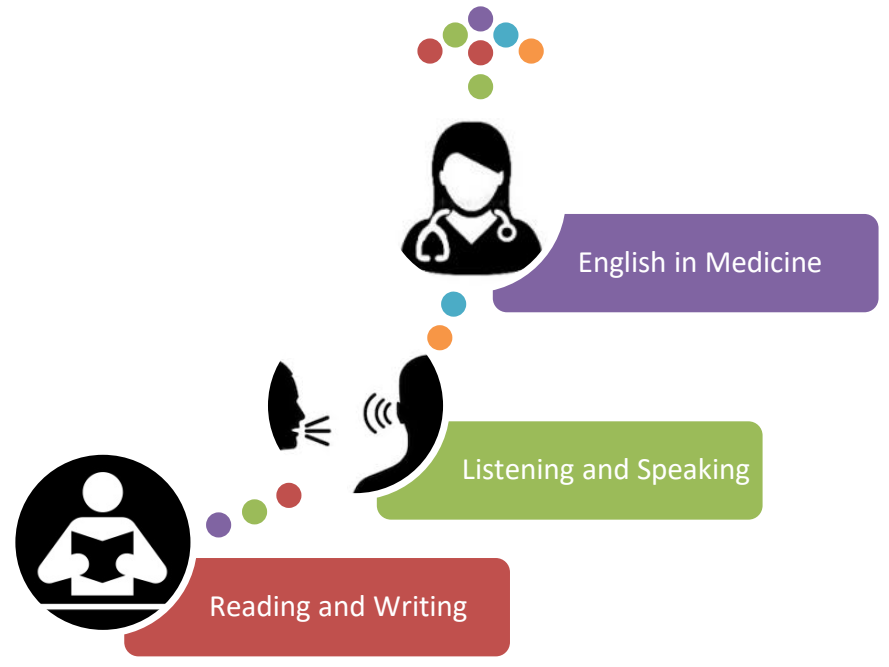

Figure 3. The division of English Language subjects in the intensive English course (019-Njl 6) taught to Medical colleges students at KKU (Adapted from King Khalid University, Joint Programs, Course descriptions, 2021)

The prescribed textbook is "English in Medicine" from Cambridge Professional English series, the third edition. The book comprises of seven units sequentially ordered from the very first doctor-patient interaction of history taking, until the last stage of treatment. Each unit is divided into parts including language focus, hospital-based conversations and speaking activities, medical vocabulary, medical reading and writing and medical case follow-ups.

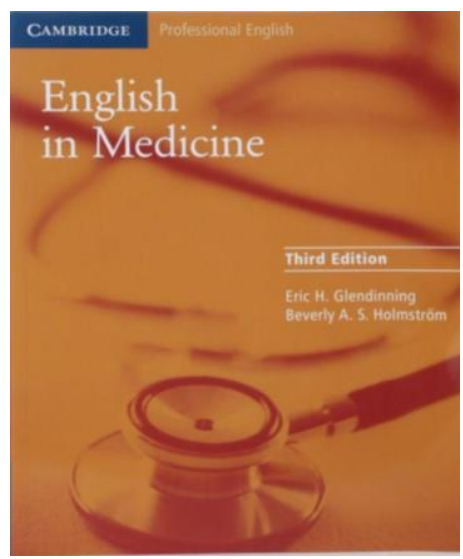

Figure 4. The prescribed textbook for Professional English for Medical colleges students at KKU

The learning outcomes of the course are stated in the course specification as following:

- Acquire medical terminology and English vocabulary familiar and routine matters. 
- Identify the communication pattern for describing students' background, environment, and their daily needs.

- Reproduce sentences and frequently used expressions related to personal and family information, shopping, local geography, employment.

- Recognize the main ideas of a text on familiar matters regularly encountered in work, school, leisure, etc.

- Identify writing techniques in the medical field.

- Communicate in day-to-day life and use medical terminology effectively.

- Improve academic and social interactions among students; and their ability to use the knowledge of different skills in spoken and written discourse.

- Develop argumentative skills.

- Talk about topics that are familiar, of personal interest or pertinent to everyday life.

- Use medical terminologies and summarize.

- Apply reading strategies - Previewing/ Skimming/ Scanning texts on familiar matters regularly encountered in the medical field.

- Write a simple text on topics related to medical field.

- Use different types of texts for different purposes/tasks

- Predict, draw conclusions

- Talk about topics that are familiar, of personal interest or pertinent to everyday life.

\section{Procedure}

The research was executed within a period of sixty-five days. The instructors' interviews were taken via the IMO app due to the social distancing measurements for covid-19 prevention. Every instructor's interview took from 1- to 15 minutes. Next, the students' questionnaire was built via google form and the participation invitation with the form link were sent to students through email. The results of interviews and questionnaire were analyzed descriptively using Microsoft Excel.

\section{Findings}

The collected data has shown important indications of particular facts about E-teaching of English for Medicine to the PY students at the ELC, KKU during the pandemic. In the first part of the questionnaire, the students as well as teachers were asked questions related to technological challenges. As shown in figures five and six, there is a sweeping agreement among almost 95\% percent of the participants that teaching and learning English in Medicine in the traditional face-to-face method is far better and more effective than online learning. Another similar percentage believed that they face technical problems while longing into the university learning management systems due to various reasons of internet connection, system collapses or device technical issues. In another question, $45 \%$ of students and $21 \%$ percent of teacher admitted having technophobia and low digital competence. 


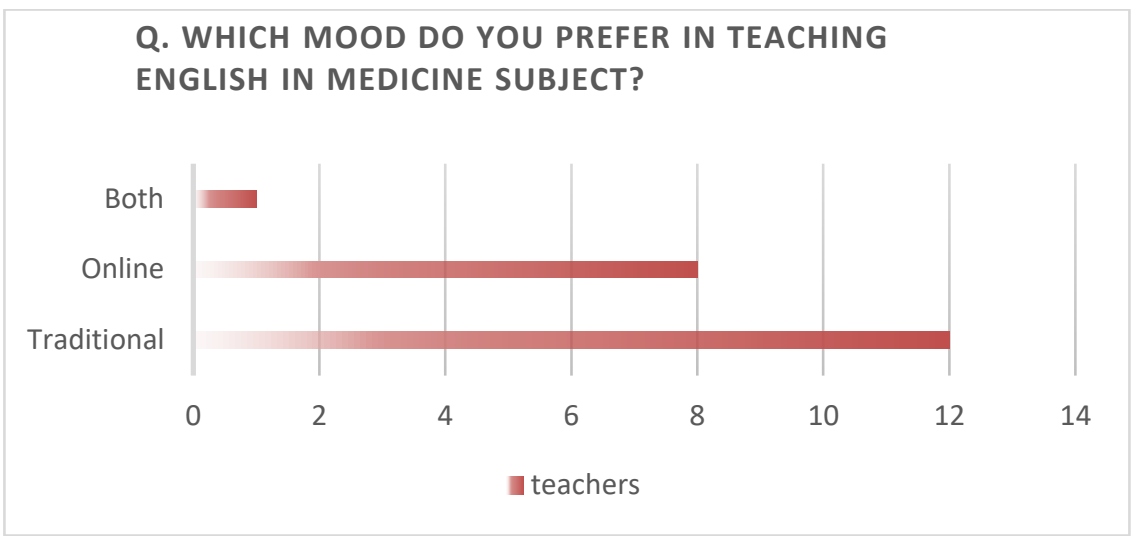

Figure 5. Teachers' response to the preferred mood of teaching

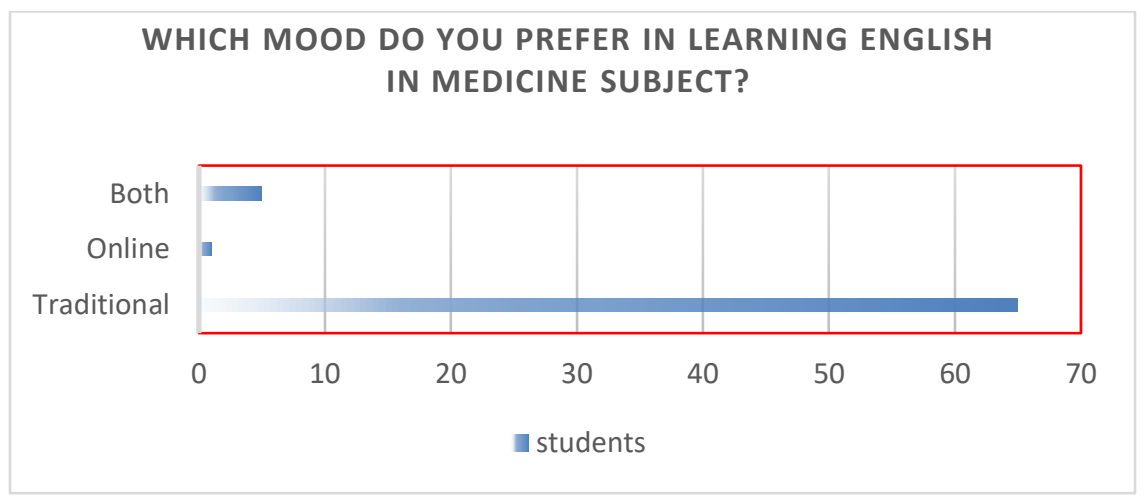

Figure 6. Students' response to the preferred mood of learning

The second part dealt with the teaching methodology. In the student's survey as shown in Figure seven, $70 \%$ of the students believed that the teaching is "teacher-centered" where teachers typically focus on translating medical terms and conversations while students only listen and write notes. Just a few agreed that teachers make them participate in the interpretation and meaning-making process. In the question related to the audio-visual aids, all the participants admitted having audio tracks of the textbook conversations. Still no interactive videos or educational movies are used to create interest in the virtual class. Only 25\% admitted that their teacher uses educational games and educational activities in the class. In another question, 80\% of the students declined to have any online communities or groups in the subject to enhance collaboration and technoparticipation in the subject. The teacher's responses to the interview supported the findings of the students' survey in this aspect as $90 \%$ of the teachers admitted using teacher-centered grammar-translation method as a primary teaching methodology and that they seldom use communicative and collaborative tools. Teachers has also complained of the lack of sources and the digital educational material of the course. This finding demonstrates the traditionality of teaching methodologies, miscommunication, and monotony in the online classes, which has a vital role in lowering students' interest in attending the classes, understanding of the subject and handicapping the learning process massively. 
Q. The teacher's methodology in the online class is techer- centered?

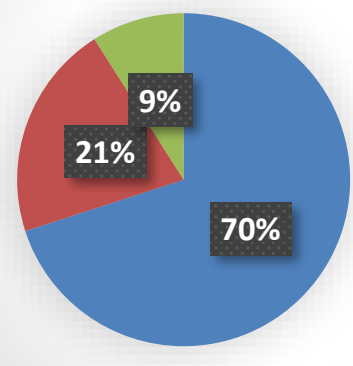

Figure 7. Students' response to the teaching methodology in the classes

Q. What teaching methodology do you adopt in your online class?

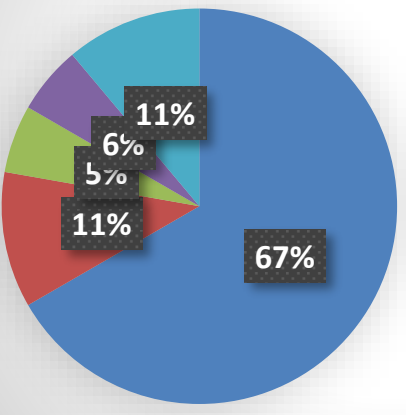

- Grammer Translation Method

n communicative Method

- Direct Method

audio-Lingual Method

Figure 8. Teachers' response to the teaching methodology in the classes.

The last section of the questionnair and interviews was related to the online assessments of the subject. In the question related to the types of online assessments the student are evaluated by, almost all students answered that subjective online BlackBoard tests are the only method of evaluation. No year work or final marks are alloted for any other types of practical assessments such oral presentations, collaborative projects, digital or virtual reality video productions or communicative profession-related tasks. In the question related to the level of difficulty of online assessments, two-third of the students believed that the exams vary from medium to low level of difficulty. Also, about $80 \%$ percent of the students assures that all the online assessments are summative evaluation that merely tests the quantity of information without assessing the actual cognitive-linguistic ability of students.

A question was asked about the attitude of the students towards the online assessments. Seveenty-percent confessed that they take online tests lightly and depend on books, google and whatsApp friends and groups in solving the online tests. Just a few students said that they prepare seriously for online tests, yet do not deny taking assistance of external help anyway. This widely doubt the credibility of these online assessments as authentic determining factors of students accurate academic level and linguistic competencies. Teachers responded identically to these questions pertaining that to the rules they get from the ELC and University E-learning committees that give them no chance to assess students pragmatically in line with the course 
objectives. Only on-campus midterm and final exams were claimed to reflect studnts' academic progess in the subject realistically.

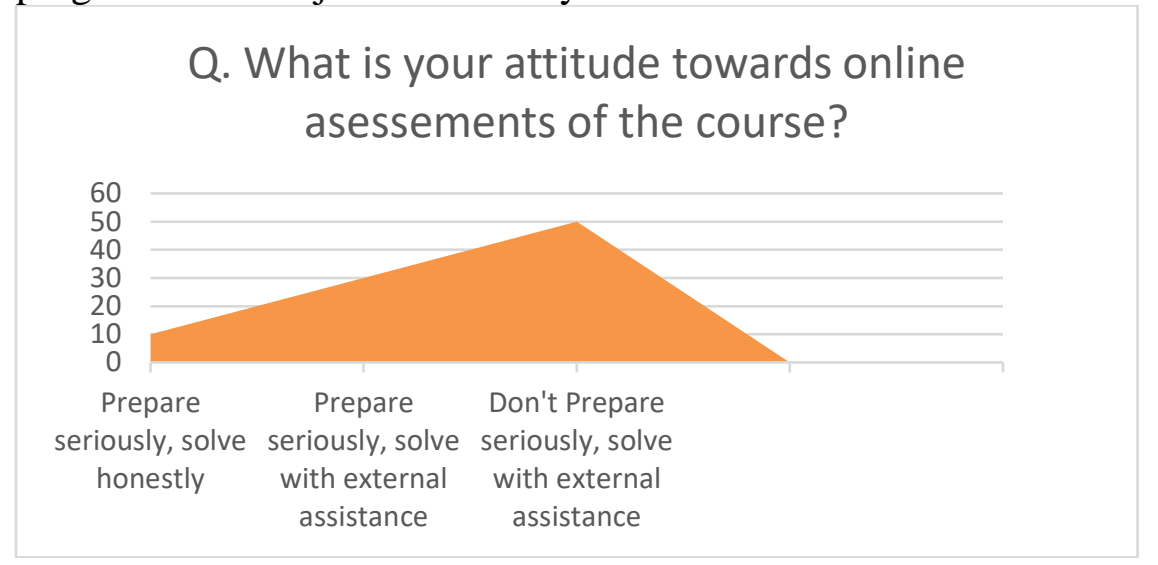

Figure 9. Students' response to attitudes towards online assessments

\section{Discussion}

From the afore-mentioned results and findings of the study, the findings of the challenges faced in E-teaching and E-learning of English in Medicine subject from both students are teachers' perspectives can be summarized as follows:

\section{Challenges related to Technology}

Due to the geographical location of the university in a mountainous region, internet issues are the most problematic issue in online teaching and learning, especially for those living remote countryside areas and villages. Internet connections are unstable and costly due to which having a good and high-speed internet connection is rare and unaffordable.

Lack of digital competence is another challenge hindering the online teaching and learning process, especially in teachers. Many teachers and several students lack the required skills to access the internet on developed devices and deal with the learning management system and its tools or engage in active teaching and learning.

Majority of the educators and the learners in the city lack computer literacy and fail to solve hardware or software-related issues on time and depend on specialized shops and computer-repair technicians that wastes a lot of time and money.

Technophobia is a significant emotional obstacle in learning ad teaching English in Medicine online. The study reported some teachers as well as students fearing the evolving technology and facing troubles using it and feeling negatively towards it. This leads to frustration which causes them to withdraw from the frustrating situation, making them do not want to continue learning or teaching in frustrating environment and putting them always under fear and pressure. This largely affects their teaching and learning performances especially in a subject as English in Medicine.

Lack of digital resources for English in Medicine is another hamper in implementing effective teaching. Authentic dictionaries of Medical terms in English are hard to find in digital form. Teachers waste a lot of effort and time in searching related resources and references or 


\section{Arab World English Journal (AWEJ) Special Issue on Covid 19 Challenges April 2021}

Technology, Pedagogy \& Assessment: Challenges of COVID19

Alvi, Bilal, \& Alvi

making it themselves. There are also some resources but are not easy to access for teachers and students. All technology-related challenges of this study support the findings of Akhter (2020), Hakim (2020) and Mahyoob (2020) which reveals that technological obstacles are the key challenges hampering effective online teaching ad learning process.

\section{Challenges related to Pedagogy}

Most of the teaching methodologies teachers adopt in online English in Medicine class are traditional and teacher-centered. These teaching methodologies give rise to students' disinterest in the subject despite its importance to their health specialties and cause passiveness in the online classroom, their failure in subject comprehension, and dependence on memorization rather than competence. This fact has resulted in low academic achievement in the course.

The Grammar-translation method most of the teachers use in teaching medical vocabulary depends totally on the teacher as the sole contributor and the students merely learning grammatical rules then applying those rules by translating sentences between the target language and the native language. There are no developed communicative or interactive teaching methodologies that engage the students and motivate them to learn, neither is there any sort learning-in-context activities which are highly important in teaching professional English. The finding corresponds with the findings of Rehman (2020) and Al-Ahdal and Al-Qasham (2020) as they also asserted the issue of teacher's lack of effective online teaching methodology as an essential requirement for successful e-teaching.

There is a lack of audio-visual aids in the online classroom. Video gaming and video production and digital resources are not used either because of the resources or the teacher's digital illiteracy. This has resulted in the monotony and ineffectiveness of the class; hence students lose interest in attending, and that harms their academic progress.

Lack of active online communities and collaboration is significantly noticed. There is miscommunication between the educator and the learner and between learners themselves. There is an absence of collaborative practice of medical English in the context which is undoubtedly essential for the productive online environment to infuse a sense of belonging and camaraderie and to keeps online learners connected and motivated.

\section{Challenges related to Evaluation}

The only approved assessment for the course is summative tests including quizzes, midterms, and finals. These tests are based on testing student's information and memorization without reflecting student's linguistic competence and understanding of the subject.

Validating the findings of Dahmash (2020), Al-Nofaie and Al-Ghammas (2020), the study finds that all online tests are objective asynchronous tests with a time limit of twelve to twentyfour hours. More than one attempt are allowed which increases the temptation to cheat causing unreal and irrational exam results and doing injustice with the accurate academic level of students.

All the evaluations in the course are subjective written exams that depends on student's memorization without practice in the context. No oral assessments are included in the assessment 


\section{Arab World English Journal (AWEJ) Special Issue on Covid 19 Challenges April 2021}

Technology, Pedagogy \& Assessment: Challenges of COVID19

Alvi, Bilal, \& Alvi

policy to achieve the learning outcomes of the course that majorly focuses on developing oral professional skills.

According to Jonathan McFarland, an associate Editor for Medical Humanities at Arts and Humanities in Higher Education online journal, "the scientific importance of English is such that, whenever I have a meeting with my residents - and I have many, both residents and meetings - I find myself emphasizing, over and over again, the need for them to learn English." (McFarland,2015, slide 55). Based on the statement of McFarland, the study recommends some suggestions for promoting the process of teaching and learning in English in Medicine online courses:

Internet connections should be stabilized and facilitated in service and price for students and teachers especially for those living in countryside and villages far from the city center. Education support initiatives and packages should be provided by government and private authorities in the concerned field.

Intensive training courses should be given to staff members and students to nurture their digital competence and enhance their technical skills. They should be trained to access the internet on developed devices and deal with the learning management system and its tools and engage in active teaching and learning.

Computer literacy should be developed so that teachers and students should not only have the ability to use technology but should be able to use it effectively to find information, evaluate sources, create content, and communicate with others effectively, and to evaluate and apply new knowledge gained from digital environments.

Technophobia-reduction programs should be launched to reduce psychological reactions to computer technology, decrease computer anxiety, enhance computer cognitions, and augment computer attitudes. Psychologically based intervention strategies should be provided, and effective computer-based education should be availed to students and teachers to aid accessing computer technology with confident and competent usage. Support and help units and groups within the university centers and departments can be established and made available for all. Financial as well as psychological supports should be given equally to all in need.

Digital resources and learning references related to English in Medicine should be made available and easily accessible for teachers and students. E-textbooks, e-dictionaries and animated reference books should be available and leading academic journals in the field of medicine should be made free to access to enhance reading skills and different educational videos and movies should be at the reach of teachers to use them in teaching.

Online teaching methodologies in English in Medicine class should be more efficient and effective as compared to on-site teaching. Teachers should maintain their digital presence utilizing a variety of diverse communication methods such as discussion boards, emails, announcements, and forums to be present in each online classroom. Plenty of opportunities to engage with the content using discussion forums and groups within the class so that students can engage in feedback and support with their fellow classmates and benefit significantly from 


\section{Arab World English Journal (AWEJ) Special Issue on Covid 19 Challenges April 2021}

actively engaging in this type of communication. Variety of learning styles should be promoted to enhance their learning capabilities and educate them about the importance of both group work and individual achievements. Using an assortment of appropriate and easily approachable resources such as digital publications, news sites, online videos and incorporating digital resources is strongly recommended.

Prudent selection of teaching methodologies that suit the course objectives and learning outcomes should be adopted instead of traditional methodologies. The focus should be given to the contextual use of the English language rather than merely translating vocabulary and grammar. Developed communicative and interactive teaching methodologies that engage the students and motivate them to learn and help them learn in context should be activated. Selfstudying, instructive and constructive approaches, flipping and adaptive learning should be triggered.

Audio-visual aids should be actively utilized in the online classroom. Video gaming and video production and digital resources should be used to boost students' interest in attending and upgrade their academic progress.

Active online communication and collaborations should be augmented to bridge the communication gap between the educator and the learner and between learners themselves and enhance the productive online practice of medical English in context. Teachers should set the communication plan and encourage students to interact through communal discussions, and inclass and out-class spaces.

Formative and open-book exams should be designed to evaluate students' comprehension and critical competence rather than assessing their memorization of medical terms and their translation.

Synchronous tests during live sessions should be given to truly reflect students' linguistic performances and do justice to their accurate progress levels. Oral assessments should be included in the assessment policy of the course to ensure achieving the learning outcomes of the course that majorly focus on developing the oral professional English language skills to practice it fluently in the medical field.

The study's recommendations substantiate the principles of Good Online Teaching Practice (GOTP) and pedagogic principles for effective online teaching introduced by Anderson \& McCormics,2005 as shown in Figure 10. In a nutshell, these principles emphasize on the consistency of Learning methods quality should be prioritized on quantity, appropriateness of student activities and the type of assessment. Learning outcomes, online learning processes, and assessment strategies should be correspondent to each other. Synchronous and asynchronous teacher-student interaction must be encouraged as a critical element for stimulating students toward excellent performance. Online pedagogy should incorporate learning strategies that promote demonstration of higher order thinking skills (analysis, synthesis, evaluation) and communication skills (writing, reading, speaking, listening). Effective team-work and collaborative sociality should be encouraged. Active and interactive should be fostered incorporating audio, video, and links to other virtual worlds to create authentic, cooperative 
problem-solving activities that enhance student to build meaningful knowledge dynamically. Nonetheless, self-directed learning should be augmented to bridge the transactional gap by motivating and instilling responsibility in students for congregating and constructing knowledge through independent and collective learning activities. As for assessments, both summative and formative assessment should be applied in online teaching to reflect on learners' progress and have delivery of valid and reliable evaluations. Feedback must be promptly given to students to reflect on what they have learned, what they still need to know, and how to assess themselves. Effective time-management and timely task completion should be boosted to establish the basis for high performance. In an online setting, it is pertinent to set clear expectations for quality student performance to encourage students to make extra efforts and perform well. Different talents and learning styles should be respected always and online activities should allocate several opportunities to tackle the various learning preferences and skills. Online teaching should have a system for effective supervision and monitoring including setting standards for students, facilitation, guiding, setting boundaries, giving effective feedback to ensure the attainment of proposed outcomes of online learning and help students to optimize learning.

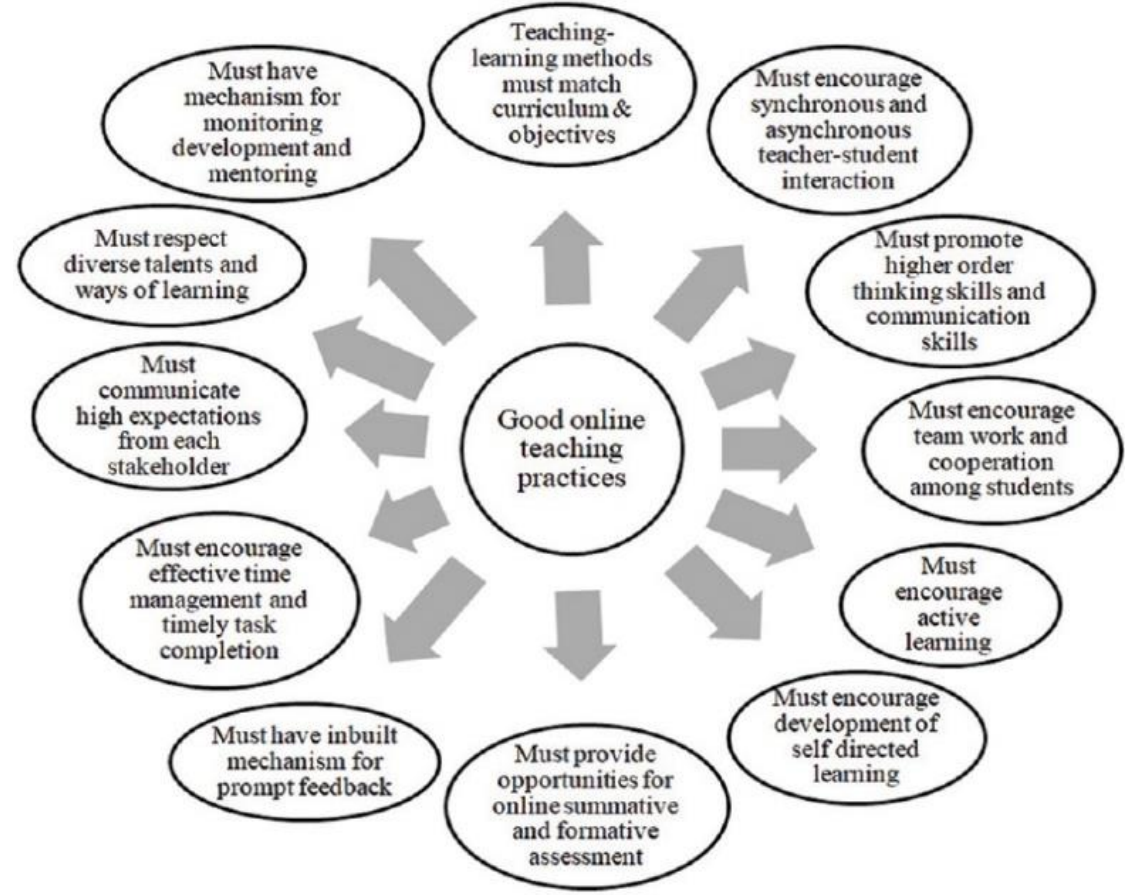

Figure 10. Recommended Principles of good online teaching practices (Adapted from Anderson \& McCormics, 2005)

\section{Conclusion}

Online teaching has been imposed to all Saudi educational institutes as an emergency social distancing measure to combat with the horrendous outbreak of Covid-19 pandemic, which consequently posed considerable challenges to teaching and learning English for Specific Purposes. The current study was intended to examine these challenges to put practical solutions to them. Data analysis revealed that there are many challenges related to technology pedagogy and evaluation. The study draws effective solutions to grant successful online learning and teaching of ESP courses including addressing technological problems, nurturing teachers' and students' digital competence and enhance their technical skills and availing digital resources for 
all. Outstanding and advanced teaching practices that incorporate configuration of the online teaching and learning with active delivery of curriculum and objectives, synchronous and asynchronous interaction between teacher and student should be adopted to reassure the development of higher-order thinking skills, active learning, and self-directed learning in students. Online assessments should be both formative and summative. Capacity building and faculty development programs for the development of competencies such as digital competency, pedagogical competency, and technical competency in the times of COVID-19 should be given paramount attention and care. This study highlights some of the aspects of the online teaching and learning process of English for Specific Purposes at one of the Saudi public universities from both teachers' and students' perspectives. Further studies are recommended for more understanding of the topics mentioned, beside other related matters, on the level of the selected university and other universities from different standpoints to utilize the potential of online teaching and learning as a flexible, learner-centered channel of boosting students self-directed learning skills, suggesting effective solutions to the challenges that hamper its successful implementation. Although online teaching and learning of medical English and ESP generally is somehow challenging, it has the potential to turn out to be a mainstream in the future.

\section{About the Authors}

Amatul Hafeez Alvi is a lecturer at KKU, Saudi Arabia. She is a PhD Scholar at UKM, Malaysia, specializing in English poetry and poetics. Her research interests include English poetry and poetics, postcolonial literature, English Language \& literature teaching.

https://orcid.org/0000-0001-9810-58877

Aisha Alvi is a PhD scholar at UTM, Malaysia, specializing in Augmented IVirtual Reality in Education. She is a lecturer at KKU, Saudi Arabia. Her research interests are computer education and human computer interaction. https://orcid.org/0000-0002-5275-0343

Syed Mohammad Bilal is an MPhil scholar at UTM, Malaysia, specializing in Mobile Assisted Learning. He is a lecturer at KKU, Saudi Arabia. His research interests are computer education and Technology in language learning. https://orcid.org/0000-0001-9694-1531

\section{References}

Akhter, T. (2020). Problems and Challenges Faced by EFL Students of Saudi Arabia during COVID-19 Pandemic. Rupkatha Journal on Interdisciplinary Studies in Humanities, 12 (5), 1-7.

Al-Ahdal, A., \& Al-Qasham, F. (2020) Saudi EFL Learning and Assessment in Times of Covid-19: Crisis and Beyond. The Asian EFL Journal, 27(3/4), 365-383.

Algaissi, A., Alharbi, N., Hassanain, M., \& Hashem A.M. (2020). Preparedness and response to COVID-19 in Saudi Arabia: Building on MERS experience. Journal of Infection and Public Health, 13(6), 834-838.

Alghammas, A. (2020). Online Language Assessment during the COVID-19 Pandemic: University Faculty Members' Perceptions and Practices. Asian EFL Journal, 27(4.4), 169-195

Almekhlafy, S. (2020). Online learning of English language courses via blackboard at Saudi universities in the era of COVID-19: perception and use. PSU Research Review, Vol. ahead-of-print No. ahead-of-print. https://doi.org/10.1108/PRR-08-2020-0026. 
Arab World English Journal (AWEJ) Special Issue on Covid 19 Challenges April 2021

Al-Nofaie, H. (2020). Saudi University Students' Perceptions towards Virtual Education during Covid-19 Pandemic: A Case Study of Language Learning via Blackboard. Arab World English Journal, 11 (3), 4-20. DOI: 10.24093/awej/vol11no3.1

Alwalidi, A., \& Lefrere, P. (2010). Making E-Learning Invisible: Experience at King Khalid University, Saudi Arabia. Educational Technology, 50 (3), 4-7.

Corbin, J., \& Strauss, A. (2008). Basics of Qualitative Research: Techniques and Procedures for Developing Grounded Theory ( $3^{\text {rd }}$ ed.). Thousand Oaks, California: Sage Publications.

Dahmash, N. (2020). 'I Couldn't Join the Session': Benefits and Challenges of Blended Learning amid COVID-19 from EFL Students. International Journal of English Linguistics, 10 (5), 221-230. DOI: 10.5539/ijel.v10n5p221

Hakim. B (2020). Technology Integrated Online Classrooms and the Challenges Faced by the EFL Teachers in Saudi Arabia during the COVID-19 Pandemic. International Journal of Applied Linguistics and English Literature, 9 (5), 33-39.

Hutchinson, T., \& Waters, A. (1987). English for Specific Purposes: A learning-centered approach. Cambridge: Cambridge University Press.

Kabir, S.M.S. (2016). Basic Guidelines for Research: An Introductory Approach for All Disciplines. Chittagong: Book Zone Publication.

Karim, M. R., \& Hasan, M. (2020). Virtual Classes during COVID 19 Pandemic in Tertiary Level in Saudi Arabia: Challenges and Prospects from the Students' Perspective. The Asian EFL Journal, 27 (5), 205-219.

King Khalid University (2021). Course Descriptions. 019 Njl. Retrieved from: https://fp.kku.edu.sa/ar/content/442

Lawthom, R., \& Tindall, C. (2011). Phenomenology. In P. Banister, G. Dunn, \& E. Burman, (Eds.) Qualitative methods in psychology: A research guide (2 ${ }^{\text {nd }}$ ed., pp.3-21). Maidenhead: Open University Press/ McGraw Hill.

Lorenzo, F. (2005) Teaching English for Specific Purposes. Available at https://www.usingenglish.com/articles /teaching-english-for-specific-purposes-esp.html

Mahyoob, M. (2020) Challenges of e-Learning during the COVID-19 Pandemic Experienced by EFL Learners. Arab World English Journal, 11(4), 351-362.

DOI: https://dx.doi.org/10.24093/awej/vol11no4.23

Mason, R., \& Rennie, F. (2008). E-Learning and Social Networking Handbook: Resources for Higher Education. Abingdon, Oxon: Routledge.

McFarland, J. (2015). The Importance of English in Medicine. [PowerPoint slides]. Slideshare. Retrieved from: https://www.slideshare.net/jonmcf/the-importance-of-english-inmedicine-3rd-december-2015

Rahman, M. M. (2020). Challenges and Solutions of Teaching English as a Foreign Language Online during a Global Pandemic like COVID-19: Saudi EFL Teachers' Perspectives. Journal of Southwest Jiaotong University, 55(6), 1-9.

UNESCO (2020). Policy Brief: Education during COVID-19 and beyond. Retrieved from: https://www.un.org/development/desa/dspd/wpcontent/uploads/sites/22/2020/08/sg_policy_brief_covid19_and_education_august_2020.pdf

World Health Organization. (2020). Coronavirus. Retrieved from: https://www.who.int/healthtopics/coronavirus\#tab=tab_1 